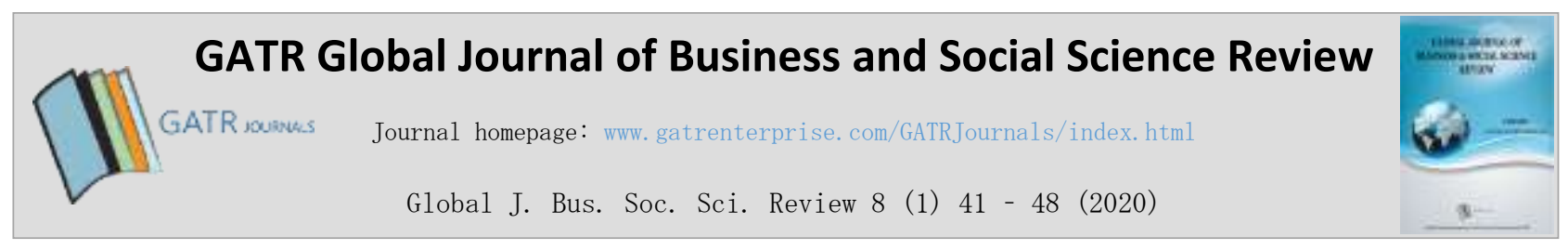

\title{
Audit Report Lag: Specialized Auditor and Corporate Governance
}

\author{
Arya Pradipta ${ }^{1 *}$, Arvivid Gracenia Zalukhu ${ }^{2}$ \\ ${ }^{12}$ Trisakti School of Management, Jl. Kyai Tapa No. 20, Jakarta, Indonesia
}

\begin{abstract}
Objective - This paper aims to obtain empirical evidence about the influence of specialized auditors, audit tenure, audit committee, board independence, ownership concentration, and auditor quality on audit report lag in Indonesian manufacturing firms.

Methodology/Technique - The population is all manufacturing companies listed on the Indonesia Stock Exchange between 2010 and 2016. Multiple linear regressions was used as the data analysis method.

Finding - The results of this research show that specialized auditors, board independence, ownership concentration and auditor quality all have an influence on audit report lag. Meanwhile, audit tenure and audit committee do not have an influence on audit report lag.

Novelty - Specialized auditors will provide better performance than non-specialized auditors. Specialized auditors will apply more appropriate planning and monitoring on the audit procedure. Specialized auditors need longer time to audit financial statements, which effects audit report lag. The presence of an independent board requires higher quality financial statements. Thus, the auditor needs to put more effort into the verification process of financial statements. The largest shareholders tend to be committed and responsible to the company's reputation. Managers will demand the audit report lag in a timely manner, in order to maintain the trust and satisfaction of the company's largest shareholders.

Type of Paper: Empirical.
\end{abstract}

Keywords: Audit Report Lag; Specialized Auditor; Board Independence; Ownership Concentration; Auditor Quality.

Reference to this paper should be made as follows: Pradipta, A; Zalukhu, A.G. (2020). Audit Report Lag: Specialized Auditor and Corporate Governance, Global J. Bus. Soc. Sci. Review 8(1): 41 - 48. https://doi.org/10.35609/gjbssr.2020.8.1(5)

JEL Classification: G30, M42.

\section{Introduction}

Audit report lag (ARL) and the factors influencing audit report lag have been the subject of interest by many researchers, academics and practitioners. Audit delay is also a different term used by researchers, which is actually related to audit report lag. Some prior studies show that audit report lag depends on firmrelated factors such as firm size, firm industry, and audit fees, and auditor-related factors (Habib \& Bhuiyan 2011).

\footnotetext{
${ }^{*}$ Paper Info: Revised: January 13, 2020

Accepted: March 31, 2020

* Corresponding author: Arya Pradipta

E-mail: arya@stietrisakti.ac.id

Affiliation: Trisakti School of Management, Jl. Kyai Tapa No. 20, Jakarta, Indonesia
} 
Some previous studies have concluded the length of the auditor-client relationship is related to audit report lag. This is referred to as "Audit Tenure". Respectively, audit tenure has been practiced and put in special regulation in many countries. A longer auditor-client relationship can improve the auditor's familiarity with the client. Therefore, some researchers show that a longer audit tenure will decrease audit report lag (Ashton et. al., 1987; Dao \& Pham, 2014; Habib \& Bhuiyan, 2011). The purpose of this research is to obtain emperical evidence about the effect of specialized auditors, audit tenure, audit committee, board independence, ownership concentration, and auditor quality on audit report lag.

This study is organized as follows. The literature review is provided in section two. Section three describes the sample and measurement of the variables. The results and discussion are reported in section four. Section five provides conclusions, limitations, and recomendations for future research.

\section{Literature Review}

\subsection{Specialized Auditors}

The specialization of the auditor industry weakens the association between short audit firm tenure and audit report lag (Dao \& Pham, 2014). This is due to the knowledge of client industries and operations during the audit engagement will reduce the audit report lag. Rustiarini and Sugiarti (2013) identified the negative effect of industry specialization on audit report lag. The results of this study indicate that firms audited by auditors with high industry specialization have low audit delays. Primadita and Fitriany (2012) also proved that the companies audited by auditors with industry specialization are shown to have low levels of information asymmetry. Therefore, the following hypothesis is proposed:

H1 Specialized auditors have an influence on audit report lag.

\subsection{Audit Tenure}

Audit firm tenure has an effect on audit report lag (Ashton et. al., 1987; Dao \& Pham, 2014). Audit firm tenure is negatively associated with audit report lag. Audit tenure does not influence audit delay (Karami et. al., 2017; Praptika \& Rasmini 2016). This is because every public accounting firm is considered to provide good services for his clients no matter how long it has been engaged with the clients. Therefore, the following hypothesis is proposed:

H2 Audit Tenure has an influence on audit report lag.

\subsection{Audit Committee Size}

The size of the audit committee is not an important determinant of effectiveness (Bédard \& Gendron, 2010). However, audit committee size has a significant negative relationship with the timeliness of financial reporting (Puasa et. al., 2014). In contrast, Verawati and Wirakusuma (2016) found that there is no influence of audit committee size on audit report lag. This is probably because the audit committee has no direct role in the preparation of the audit report but acts only as a supervisor in the preparation of the auditor's report. Therefore, the following hypothesis is proposed:

H3 Audit committee size has an influence on audit report lag. 


\subsection{Audit Committee Expertise}

Based on corporate governance guidelines, audit committee members must have a balance of skills and experience and should have a good understanding of financial reporting (Wardhani \& Raharja, 2013). The increasing number of audit committee members who have competence in finance and accounting will shorten the company's audit report lag. However, audit committee expertise does not have any relationship with audit report lag (Apodore \& Noor, 2013). This indicates that there is no association between audit committee expertise and the audit report lag. This result is consistent with the findings of Aljaaidi et. al. (2015). Therefore, the following hypothesis is proposed:

H4 Audit committee expertise has an influence on audit report lag.

\subsection{Audit Committee Meeting}

There is no relationship between an audit committee and audit report lag (Mohamad-Nor et. al., 2010). Wardhani and Raharja (2013) explain that this is because the more frequent meetings itself may probably make too much consideration when it comes to making decisions, which may increase audit report lag. Therefore, the following hypothesis is proposed:

H5 Audit committee meeting has an influence on audit report lag.

\subsection{Board Independence}

There is a strong relationship between audit report lag and board independence, but this relationship is not significant (Apadore \& Noor, 2013). Board independence is significantly associated with audit report lag (Afify, 2009). This means that an independent board can have a positive impact on financial disclosure quality and reduce audit report lag. Therefore, the following hypothesis is proposed:

H6 Board independence has an influence on audit report lag.

\subsection{Ownership Concentration}

Ownership concentration in one of the independent variables that mainly influences audit report lag and corporate governance in public listed companies in Malaysia (Apadore \& Noor, 2013). Ownership concentration reflects the audit business risks but the coefficient estimate for ownership concentration is not significant (Henderson \& Kaplan, 2000). Although the relationship is insignificant, it is considered to reach expectations (Afify, 2009). Ownership concentration positively affects the accepted voluntary disclosure (Nuryaman, 2009). This means that the greater the shares owned by the majority shareholder (largest ownership), voluntary disclosure of financial statements will increase. Therefore, the following hypothesis is proposed:

H7 Ownership concentration has an influence on audit report lag.

\subsection{Auditor Quality}

Auditor quality has a positive and significant influence on audit report lag (Kartika, 2009). Companies that receive an unqualified opinion have a faster audit time than a company that receives a qualified opinion. Audit quality affects the credibility of financial statements when the company is a public entity. Therefore, underwriters who have high reputation, demand the guarantee that the company will hire an auditor firm with 
a high reputation. A reputable auditor firm will have more qualified human resources (auditor) which can work effectively. Auditor quality has an influence on Audit Delay (Widosari \& Rahardja, 2012). This is because the firm affiliated with big four auditing can complete audits faster because they have greater resources. Therefore, the following hypothesis is proposed:

H8 Auditor quality has an influence on audit report lag.

\section{Research Methodology}

The research sample criteria are summarized in Table 1 below.

Table 1. Sampling Procedures

\begin{tabular}{llll}
\hline No. & Criteria Description & Firms & Data \\
\hline $\mathbf{1}$ & $\begin{array}{l}\text { Manufacturing companies consistently } \\
\text { listed in IDX from } 2010 \text { until } 2016 .\end{array}$ & 372 \\
$\mathbf{2}$ & $\begin{array}{l}\text { Manufacturing companies that do not (14) } \\
\text { consistently published audited financial } \\
\text { statements. }\end{array}$ & \\
$\mathbf{3}$ & $\begin{array}{l}\text { Manufacturing companies that do not have } \\
\text { closing period report date on } 31\end{array}$ \\
& $\begin{array}{l}\text { December. } \\
\mathbf{4} \\
\text { Manufacturing companies that do not } \\
\text { provide complete data and information of } \\
\text { audit committee aspects in their financial } \\
\text { statements. } \\
\text { Number of sample firms used }\end{array}$ \\
\hline
\end{tabular}

Audit report lag is measured as the number of calendar days from fiscal year-end to the date of the auditor's report (Dao \& Pham, 2014). An auditor is a specialist if the auditor firm holds $15 \%$ of total firms in one industry group (Primantara \& Rasmini, 2015). According to the Indonesian Stock Exchange, there are three industrial classifications for manufacturing companies: Basic Chemical Industry Sector, Various Industries Sector, Industry and Consumer Goods Sector. Specialized auditors are measured by number of firms audited by the same auditor in the same industry divided by the number of firms audited by all auditors in the same industry (Jensen, 1970). Auditor tenure is based on the number of consecutive years a firm is audited by a particular audit firm (Rustiarini \& Sugiarti, 2013). In this research, the indicator variable is coded 1 for firm-year observations with auditor tenure equals to five years and 0 otherwise.

The number of audit committee members (Apodore \& Noor, 2013) is measured by audit committee size. The data is taken from the audit committee profile provided in the financial report. The audit committee is assumed to have expertise if the member meets one of the following requirements: (1) Member who has accounting or financial education background; (2) Member who has working experience in accounting or finance. Audit committee meetings are measured based on the number of audit committee meetings carried out annually (Apadore \& Noor, 2013).

Board independence is measured as the proportion of independent directors (independent commissioners) on the board (Apadore \& Noor, 2013). The proportion of common shares held by the largest shareholder (Leung \& Liu, 2015) indicates ownership concentration. Auditor quality is measured as variable dummy that defines the level of auditor's reputation, in which a value of 1 will be assigned to companies audited by the Big 4 public accounting firm, and 0 otherwise (Mukhtaruddin et. al., 2015). 


\section{Results and Discussion}

The result from the descriptive statistics are summarized in Table 2 below.

Table 2. Descriptive Statistics

\begin{tabular}{|c|c|c|c|c|}
\hline $\begin{array}{c}\text { Var } \\
\text { iabl } \\
\text { e }\end{array}$ & $\begin{array}{c}\text { Min } \\
\text { imu } \\
\mathrm{m}\end{array}$ & $\begin{array}{c}\mathrm{M} \\
\mathrm{ax} \\
\mathrm{i} \\
\mathrm{m} \\
\mathrm{u} \\
\mathrm{m}\end{array}$ & $\begin{array}{c}\mathrm{Me} \\
\text { an }\end{array}$ & $\begin{array}{c}\text { Std. } \\
\text { Deviati } \\
\text { on }\end{array}$ \\
\hline $\begin{array}{c}\text { AR } \\
\mathrm{L} \\
\mathrm{AC}\end{array}$ & 40 & $\begin{array}{c}15 \\
1\end{array}$ & $\begin{array}{c}77.4 \\
3\end{array}$ & 13.850 \\
\hline $\begin{array}{c}\mathrm{SIZ} \\
\mathrm{E} \\
\mathrm{AC}\end{array}$ & 2 & 5 & 3.12 & 0.406 \\
\hline $\begin{array}{c}\mathrm{EX} \\
\mathrm{P} \\
\mathrm{AC}\end{array}$ & 0 & 4 & 2.40 & 0.726 \\
\hline $\begin{array}{l}\text { ME } \\
\text { ET }\end{array}$ & 2 & 33 & 6.94 & 5.030 \\
\hline $\begin{array}{r}\text { BI } \\
\text { ND }\end{array}$ & $\begin{array}{c}0.16 \\
7\end{array}$ & $\begin{array}{c}0 . \\
80 \\
0\end{array}$ & $\begin{array}{l}0.41 \\
774\end{array}$ & $\begin{array}{c}0.11161 \\
8\end{array}$ \\
\hline $\begin{array}{c}\mathrm{O} \\
\mathrm{W} \\
\mathrm{NC} \\
\mathrm{ON}\end{array}$ & $\begin{array}{c}0.10 \\
2\end{array}$ & $\begin{array}{c}0 . \\
99 \\
1\end{array}$ & $\begin{array}{l}0.53 \\
632\end{array}$ & $\begin{array}{c}0.23070 \\
5\end{array}$ \\
\hline
\end{tabular}

Table 3. Hypothesis Test Results

\begin{tabular}{ccc}
\hline Variable & B & Significance \\
\hline SPEC & 0.212 & 0.010 \\
TEN & 0.085 & 0.217 \\
ACSIZE & - & 0.675 \\
& 0.029 & 0.344 \\
ACEXP & 0.060 & 0.258 \\
ACMEET & - & 0.000 \\
BIND & 0.078 & 0.001 \\
OWNCON & 0.256 & 0.000 \\
& - & 0.223 \\
\hline
\end{tabular}

The significance level of audit tenure (TEN), audit committee size (ACSIZE), audit committee expertise (ACEXP) and audit committee meeting (ACMEET) are consecutively $0.217 ; 0.675 ; 0.344$ and 0.258 . These four variables have a significance level greater than 0.05 which means that $\mathrm{H} 2, \mathrm{H} 3, \mathrm{H} 4$, and $\mathrm{H} 5$ are all rejected.

Specialized auditors (SPEC) has a significance level of 0.010 which is below 0.05 . This shows that auditor industry specialization has an influence on audit report lag. The specialized auditor has a positive 
influence on audit report lag, which indicates a positive relationship between specialized auditors and audit report lag. This is most likely because specialized auditors tend to maintain a good reputation and relationship with clients. As a result, specialized auditors will provide better performance than nonspecialized auditors. To deliver high performance on audit work, specialized auditors will apply more appropriate planning and monitoring on audit procedures. Thus, specialized auditors need a longer time to audit the financial statements which in turn increases audit report lag.

Board independence (BIND) has a significance level of 0.000. This means that board independence has an influence on audit report lag. The coefficient of board independence is 0.256 which means there is a positive relationship between board independence and audit report lag. Board independence has a positive influence on audit report lag. The positive influence indicates that the presence of independent management requires higher quality financial statements and quality audits. Thus, the auditor needs to put more effort into the verification process (Yaacob \& Che-Ahmad, 2012).

Another independent variable that has an influence on audit report lag is ownership concentration (OWNCON). The coefficient of ownership concentration is -0.223 which means there is a negative relationship between ownership concentration and audit report lag. Ownership concentration has a negative influence on audit report lag. It is assumed that the greater proportion of ownership concentration, the shorter audit report lag is. The largest shareholders will have great power to control and monitor the functions of management. This also indicates that the largest shareholder tends to be committed and responsible to the company reputation, hence, managers will demand the auditor report the financial statements in a timely manner, in order to maintain the trust and satisfaction of the largest shareholders (Butarbutar \& Hadiprajitno, 2017).

The last independent variable in this research is auditor quality (AUDQ) which has a significance level of 0.000 . The coefficient of auditor quality is -0.327 . It is therefore concluded that there is a negative relationship between auditor quality and audit report lag. Auditor quality also has a negative influence on audit report lag. This negative relationship means that auditors of the Big Four can possibly reduce audit report lag. The corporate managers may be motivated to hire high-quality auditors as these auditors are expected to perform an audit effectively and efficiently (Rusmin \& Evans, 2017).

\section{Conclusion}

Based on this research, it can be concluded that specialized auditors, board independence, ownership concentration and auditor quality have an influence on audit report lag, while the other four variables do not have an influence on audit report lag. There are some limitations to this research. The research period in this study is relatively short, being only three years. Further, the research sample is focused only on listed manufacturing firms, so the results cannot be generalized for all industries. This research uses relatively less samples due to the criteria of the research. This research is also limited to audit firm tenure of five years proxy as firm rotation rules are no longer restricted and some previous independent auditor financial statements are unavailable to download. This research defines specialized auditor in line with the definition developed by Primantara and Rasmini (2015) without testing another proxy. The manufacturing industry classification used in this research is limited to three categories of the industry without considering subindustries to measure the specialized auditors.

Hence, future research should extend the study period and carry out the research on other industries in addition to manufacturing companies. Further, future research samples are expected to be expanded, different proxies of audit tenure should be used and a longer audit tenure should be observed. Future research should also use additional different industry specialization percentage proxies such as $10 \%$ and $30 \%$ of the total number of manufacturing firms. Different proxies may also be used. Finally, future research should consider sub-industry classification to measure specialized auditors. 


\section{References}

Afify, H. A. E. (2009). Determinants of audit report lag-Does implementing corporate governance have any impact? Empirical evidence from Egypt. Journal of Applied Accounting Research 10(1): 56-86. https://doi.org/10.1108/09675420910963397

Aljaaidi, K.S., Bagulaidah, G.S., Ismail, N.A., \& Fadzil, F.H. (2015). An Empirical Investigation of Determinants Associated with Audit Report Lag in Jordan. Jordan Journal of Business Administration 11(4).

Apadore, K., \& Noor, M.M. (2013). Determinants of Audit Report Lag and Corporate Governance in Malaysia. International Journal of Business and Management 8(15).

Ashton, R.H., Willingham, J.J., \& Elliott, R.K. (1987). An Empirical Analysis of Audit Delay. Journal of Accounting Research 25(2). https://www.jstor.org/stable/2491018?seq=1\#metadata_info_tab_contents

Butarbutar, R. S. K., \& Hadiprajitno, P. B. (2017). Analysis of Factors Affecting the Audit Lag Report (Empirical Study of Manufacturing Companies Listed on the Indonesia Stock Exchange in 2012-2015). Diponegoro Journal of Accounting, 6 (3), 50-61.

Dao, M. \& Pham, T. (2014). Audit tenure, auditor specialization and audit report lag. Managerial Auditing Journal 29(6): 490-512.

Firnanti, F. (2016). Factors that influence Audit Report Lag. Journal of Business and Accounting 18 (2): 167-175.

Habib, A., \& Bhuiyan, M.B.U. (2011). Audit firm industry specialization and the audit report lag. Journal of International Accounting, Auditing and Taxation 20: 32-44.

Henderson, B. C., \& Kaplan, S. E. (2000). An examination of audit report lag for banks: A panel data approach. Auditing: A Journal of Practice \& Theory, 19(2), 159-174. https://doi.org/10.2308/aud.2000.19.2.159

Jensen, M. C., \& Meckling, W. H. (1979). Theory of the firm: Managerial behavior, agency costs, and ownership structure. In Economics social institutions (pp. 163-231). Springer, Dordrecht. https://link.springer.com/chapter/10.1007/978-94-009-9257-3_8

Karami, G., Karimiyan, T. \& Salati, S. (2017). Auditor Tenure, Auditor Industry Expertise, and Audit Report Lag: Evidences of Iran. Iranian Journal of Management Studies 10(3): 641-666. https://doi.org/10.22059/IJMS.2017.219348.672346

Kartika, A. (2009). Factors Affecting Audit Delay in Indonesia (Empirical Study of LQ 45 Companies listed on the Jakarta Stock Exchange). Journal of Business and Economics 16 (1): 1-17.

Mande, V., \& Son, M. (2011). Do audit delays affect client retention? Managerial Auditing Journal 26(1): 32-50.

Mohamad-Nor, M.N., Shafie, R., \& Wan-Hussin, W.N. (2010). Corporate Governance and Audit Report Lag in Malaysia. Asian Academy of Management Journal of Accounting and Finance 6(2): 57-84. https://papers.ssrn.com/sol3/papers.cfm?abstract_id=1695085

Mukhtaruddin, R.O., Relasari, \& Abukosim. (2015). Firm and Auditor Characteristics, and Audit Report Lag in Manufacturing Companies Listed on Indonesia Stock Exchange during 2008-2012. Expert Journal of Business and Management 3(1): 13-26.

Nuryaman. (2009). The Effect of Ownership Concentration, Company Size, and Corporate Governance Mechanisms on Voluntary Disclosure. Journal of Accounting and Finance Indonesia 6 (1).

Praptika, P.Y.H., \& Rasmini, N.K. (2016). Effects of Audit Tenure, Auditor Change and Financial Distress on Audit Delay in Consumer Goods Companies. E-Journal of Accounting, Udayana University 15 (3).

Primadita, I., \& Fitriany. (2012). The Effect of Tenure Audit and Specialist Auditors on Asymmetry Information. Journal and Proceedings of the SNA - National Symposium on Accounting, 15.

Primantara, I.M.D., \& Rasmini, N.K. (2015). Effect of Industry Type, Auditor Industry Specialization and Auditor Opinion on Audit Delay. E-Journal of Accounting, Udayana University 13 (3).

Puasa, S., et al. (2014). Audit Committee and Timeliness of Financial Reporting: Malaysian Public Listed Companies. Middle-East Journal of Scientific Research 22(2): 162-175.

Rusmin, R., \& Evans, J. (2017). Audit quality and audit report lag: Case of Indonesian listed companies. Asian Review of Accounting 25(2).

Rustiarini, N.W., \& Sugiarti, N.W.M. (2013). Effect of Auditor Characteristics, Audit Opinion, Audit Tenure, Change of Auditors on Audit Delay. Scientific Journal of Accounting and Humanities 2 (2).

Verawati, N.M.A., \& Wirakusuma, M.G. (2016). Effects of Auditor Substitution, KAP Reputation, Audit Opinion and Audit Committee on Audit Delay. E-Journal of Accounting, Udayana University 17 (2). 
Wardhani, A.P. \& Raharja, S. (2013). Analysis of the Effect of Corporate Governance on Audit Lag Report. Diponegoro Journal of Accounting 2 (3).

Widosari, S.A., \& Rahardja. (2012). Analysis of Factors That Influence Audit Delays in Manufacturing Companies in the Indonesia Stock Exchange in 2008-2010. Department of Accounting, Faculty of Economics and Business, Diponegoro University 1 (1): 1-13.

Yaacob, N.M., \& Che-Ahmad, A. (2012). Adoption of FRS 138 and Audit Delay in Malaysia. International Journal of Economics and Finance 4(1). 